\title{
Key Success Factors for Public Private Partnership in Urban Renewal in Jakarta
}

\author{
Hary Agus Rahardjo, Fitri Suryani, and S. T. Trikariastoto
}

\begin{abstract}
Urbanization is not limited to people who earn enough, but also encourage the community under the less educated and skilled to move and settle in Jakarta. These were the ones who often later created his own living environment in the wild, illegal, unhealthy, dense and seedy. It is the government's duty and responsibility to regulate the housing environment in order to fulfill citizens' welfare. Problems arise when the ability of the government budget is not enough to finance the improvement of slum areas. For those reasons, the government should invite other parties to jointly improve the neighborhoods in question. Facts have shown that during this time, the cooperation between the government and the private sector has always failed to transform the slum. This paper will explore the factors causing the failure of which is then used as a key success factor of public-private partnerships for urban renewal in Jakarta.
\end{abstract}

Index Terms -Public private partnership, urban renewal.

\section{INTRODUCTION}

In line with the rapid economic growth and the development of more advanced city, Jakarta becomes a destination for immigrants. They come to work, and get better urban amenities, such as educational facilities, health, shopping, entertainment and leisure facilities. Urbanization is not limited to people who earn enough, but also encourage the community under the less educated and less skilled to move and settle in Jakarta. This low income society generally intends to get a better life. These were the ones who often later created his own living environment in the wild, illegal, without pay attention to the health aspects of the environment, dense and seedy. Healthy living environment is very important. Affect health to neighborhoods is not only the physical health of the occupants, but also affect the mental health, spiritual and social health of the occupants. Stress, depression, and other mental illnesses are often cause by unhealthy environment as a place to live. Fighting between residents and the increasing criminal acts are also triggered by circumstances dense neighborhoods, socially unhealthy. The environment does not provide enough space for people to hang out and mingle occupants. It is the duty and responsibility of the government to regulate the housing environment in order for the welfare of its citizens [1]. Problems arise when the ability of the government budget, in this case the local government, is not enough to finance the

Manuscript received April 10, 2013; revised July 15, 2013.

Hary Agus Rahardjo is with the University of Persada Indonesia YAI, Jakarta, Indonesia (e-mail: rahardjo30@yahoo.com).

Fitri Suryani is with the University of Persada Indonesia YAI, Jakarta, Indonesia (e-mail: fitrie_soerjanie@yahoo.co.id).

S. T. Trikariastoto is with the University of Persada Indonesia YAI, Jakarta, Indonesia (e-mail: trikarias@yahoo.com). improvement of slum areas. For those reasons, the government should invite other parties to jointly improve the neighborhoods in question [2]. Facts have shown that during this time, the cooperation between the government and the private sector has always failed to transform the slum. For that, we need to examine what factors causing the failure of the establishment of such cooperation; what the actual desires of the communities; how did the causality of the problem structuring seedy neighborhood, community expectations, and cause of failure and so on. This paper will explore the factors causing the failure of which is then used as a key success factor of public-private partnerships for urban renewal in Jakarta.

\section{RESEARCH APPROACH}

The research will be conducted in the housing authorities and associated private associations of a major municipal housing authority. Participants will be selected by directly contacting them using contact information available from the housing authority Web site or other contact information.

The Survey approach is done by questions. These survey questions are intended to provide information for a qualitative survey of affordable housing and the use of public-private partnerships. It can be distributed to individuals at a range of levels in the organization, which will allow for the development of a range of views. The sampling method that will be used for the study is a purposive selection method, in which the participants are selected according to their suitability for participation in the study [3].

The interview process will consist of interviewing one or two long-term, high-level employees of the housing authority selected who has been involved in setting and administering the public-private partnership model for affordable housing. This interview will be intended as a semi-guided interview that will provide an in-depth analysis of the origins and effectiveness of the public-private partnership model in the organization.

The scope of this research focuses on the development of housing for low income people which is implemented by the private sector in collaboration with the government. Case studies will be conducted in Northern Jakarta area.

\section{RESUlT AND DisCUSSION}

\section{A. Overview of Jakarta City}

Jakarta is a city with an average growth rate of 3.08\% (1980-1990). Total population is based on the estimation of Jakarta National Socio-Economic Survey 2007, there were 9.06 million people, and with an area of $662.33 \mathrm{~km}^{2}$ means 
that population density reached 13.7 thousand $/ \mathrm{km}^{2}$, makes the most populous regions in Indonesia. Administrative area of Jakarta is divided into five regions and one city administration administrative districts, namely: South Jakarta Administration City, East Jakarta, North Jakarta, West Jakarta and North Jakarta, each with a vast land area of $141.27 \mathrm{~km}^{2} ; 188,03 \mathrm{~km}^{2} ; 48.13 \mathrm{~km}^{2} ; 129.54 \mathrm{~km}^{2} 146.66 \mathrm{~km}^{2}$ and an administrative district Thousand Islands $870 \mathrm{~km}^{2}$ [4].

\section{B. Urban Renewal Activities}

Urban areas naturally is an area that can be an important driver of growth for a country, especially if it is well managed and adequately. Instead, the city will not be able to function as a driver of growth and even creates a disincentive for growth if management is done in ways that are not appropriate. The ultimate goal to be achieved is to create a city that living-friendly, comfortable and able to support in competing with other cities in the world.

TABLE I: THE POPULATION DENSITY IN JAKARTA.

\begin{tabular}{|c|c|c|c|}
\hline City & Area $\left(\mathbf{k m}^{2}\right)$ & Population & $\begin{array}{l}\text { Population Density } \\
\left.\text { (people } / \mathbf{k m}^{2}\right)\end{array}$ \\
\hline South Jakarta & 141,27 & 2.190 .930 & 14.872 \\
\hline East Jakarta & 188,03 & 2.421 .419 & 12.878 \\
\hline Center Jakarta & 48,13 & 889.680 & 18.485 \\
\hline West Jakarta & 129,54 & 2.172 .878 & 16.774 \\
\hline North Jakarta & 146,66 & 1.453 .106 & 9.908 \\
\hline Thousand Island & 8,7 & 19.980 & 2.297 \\
\hline Total & 662,33 & 9.057 .993 & 13.676 \\
\hline
\end{tabular}

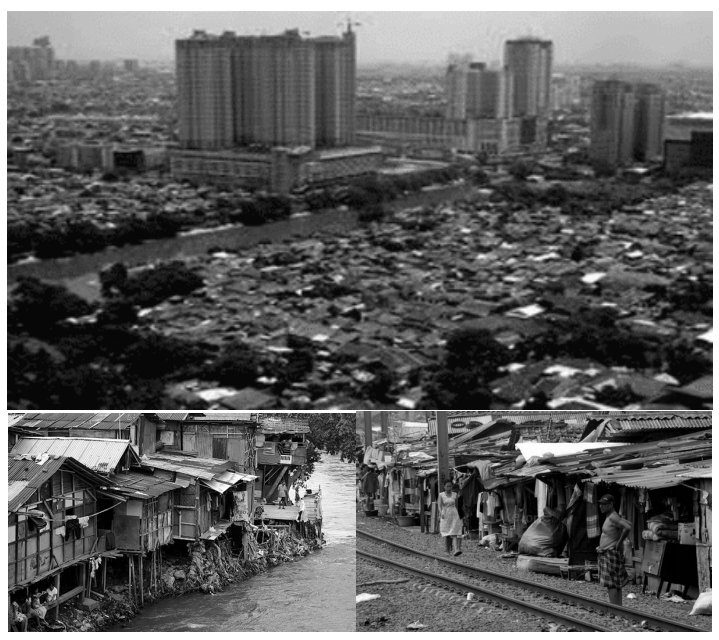

Fig. 1. Jakarta's neighborhood

One of policy as a strategy for the future that can be applied is urban renewal. This strategy is done with the realignment of the region to achieve the optimal use of each plot of land in accordance with the existing urban functions have been outlined. Urban renewal is aimed at improving people's living conditions and the quality of the urban environment, and the sustainability of local communities in various aspects of economic sustainability, environmental sustainability and social sustainability [5]. Urban Renewal is done when the city experienced a setback function, so it should be raised again in his new function. Urban Renewal related to four main points in the infrastructure, namely: housing and settlement, transportation, energy security, and clean water.

Urban renewal arrangement includes two regions, namely the CBD areas and slum areas. This study focuses on the problem of slums, considering the arrangement of the CBD can be done by the private sector in full, as it gives a clearer economic impact. Arrangement of physical facilities for the community is very important, because it is the basis for the system of economic and social life [6]. Jakarta city's economic growth looks do not automatically provide benefits for all citizens. Many people are still living in Jakarta slum region. Of the four areas of the city in Jakarta, North Jakarta is a city with the largest population and the highest density. With a relatively low level of income, the city of North Jakarta is also the city with the largest number of slums. Indonesian government through the ministry of public housing, which was formed specifically to address the issue of housing, have a real program in providing housing for the community. Thus households in developing countries value homeownership more than households in advanced industrialized countries. However, acquiring access to a home and to the components that comprise housing and housing policy - land and property rights, building materials, basic services, regulations, subsidies, and credit-are extraordinarily difficult for most households in emerging countries [7]. This situation is also happen in Indonesia.

\section{Patterns of Cooperation}

Possible patterns of cooperation are cooperation among government agencies, or public-private partnerships. This study emphasized on cooperation between the government, private sector and communities.

Public Private Partnerships can be defined as a relationship that tied with a contract, which the private sector is responsible for taking over the government task, either partially or wholly. The task in question is, for example concerning the construction of public facilities or other public services [8].

A housing PPP involves a contract between the private sector and the Government. Typically, the private sector could take on all or most of the risks associated with long term management responsibilities, rather than acting solely as an ender. These risks would include financing, construction, facilities management and risk associated with movements in property values [9].

Public-private partnerships are seen in a wide variety of settings and in heterogeneous forms that challenge the traditional theories of governance. In particular, they represent a strong expansion of regime theory, which attempts to explain how governments enact their civil and political goals [10]. There are three kinds of structuring PPPs in slum areas, namely: (a) direct demand subsidy programs, (b) microfinance of housing, and (c) low-income land development [11].

During this time, the arrangement of public private partnerships in the slums has never succeeded. One of the main problems with public-private development, both in theory and in practice, is that there is an overarching focus on the needs of the initial parties (the government and private developers) and less focus on the needs of the end users of the housing or other services that are being provided [12]. There is also a conflict stemming from the involvement of a private party driven by the profit motive - the conflict between the profit maximization motive and the requirement for specific services for the beneficiaries [8]. In addition, there is also 
resistance from the community. Structuring slum has removed their livelihood, as new settlements have him away from the location where they earn a living everyday. Urban renewal frequently has been known as the synonym for urban removal [13]. However, from the research that has been done, gives an overview of the following.

\section{Discussion against Risk Ranking}

Through the analysis of risk ranking of research data, the results obtained with the 2 way risk ranking analysis, mathematical and AHP. While the mathematical analysis obtained 3 kinds of risk level, the risk ranking based on the degree of influence, risk ranking based on the frequency and level of risk ranking based on risk level. For analysis using AHP software, we get sorts of risk level 1. This discussion is taking the top 10 greatest impact on the development of the application of the PPP settlement with questionnaire data 1 , as listed in the following Table II.

TABEL II. THE GREATES IMPACT ON THE DEVELOPMENT

\begin{tabular}{|l|l|l|l|}
\hline & Variable & $\begin{array}{l}\text { Risk Factor } \\
\text { Score }\end{array}$ & Risk Factor \\
\hline 1 & $\mathrm{X} 9$ & 42.019 & $\begin{array}{l}\text { Lack of reinforcement for legal cooperation } \\
\text { agreements involving two parties }\end{array}$ \\
\hline 2 & $\mathrm{X} 13$ & 41.588 & Lack of Good Governance \\
\hline 3 & $\mathrm{X} 14$ & 38.735 & In-Equalization project vision \\
\hline 4 & $\mathrm{X} 31$ & 38.469 & Unequal benefits for the parties involved \\
\hline 5 & $\mathrm{X} 4$ & 37.842 & $\begin{array}{l}\text { Change of mandate / authority within the } \\
\text { government structure }\end{array}$ \\
\hline 6 & $\mathrm{X} 32$ & 37.194 & Lack of funding from the private sector \\
\hline 7 & $\mathrm{X} 30$ & 37.046 & Financial constraint \\
\hline 8 & $\mathrm{X} 12$ & 36.762 & Un proportional in sharing of risk burden \\
\hline 9 & $\mathrm{X} 2$ & 36.425 & $\begin{array}{l}\text { Inability to improve the structure of the } \\
\text { agreement }\end{array}$ \\
\hline 1 & $\mathrm{X} 11$ & 36.319 & Inaccuracy of the government promise \\
0
\end{tabular}

\section{E. The Expected Public Infrastructure Facilities}

We need to explore public opinion on this subject to determine the most needed infrastructure in order to identify the infrastructure capacity and reliability that should be improved. Infrastructure facilities are needed to support the activities of community life that will ultimately affected the capacity of the region. In addition, the determination of such infrastructure can provide an overview of the need for investment, particularly associated with the expansion of the application of the principles of public-private partnerships. Low-income people give an opinion as follows: $51 \%$ need the increase in settlements, $21 \%$ increase in transport, $17 \%$ increase in clean water, $7 \%$ increase in energy (electricity and gas), $4 \%$ other infrastructure improvements. While the middle and upper gave the following opinion: $42 \%$ need the increase in housing, transportation $29 \%$, electricity and gas $18 \%$, and $11 \%$ replied require clean water infrastructure improvements.

\section{CONCLUSION}

Based on the research that has been done along with the results of analysis and discussion, it can be concluded that:

1) Key success factors in the implementation of public-private partnerships are significant in the development of slum areas, namely:

- strengthening of the legal aspects of cooperation agreements involving two parties (X9)

- good governance (X13)

- equalization / equalization vision project (X14)

- equal benefits for the parties involved (X31)

- determination of mandate/ authority within the government structure (X4)

2) For infrastructure improvements needed: low-income people give an opinion as follows: $51 \%$ increase in settlements, $21 \%$ increase in transport, $17 \%$ increase in clean water, $7 \%$ increase in energy (electricity and gas), $4 \%$ other infrastructure improvements. While the middle and upper gave the following opinion: $42 \%$ increase in housing, transportation $29 \%$, electricity and gas $18 \%$, and $11 \%$ replied require clean water infrastructure improvements.

Results of this study will be a recommendation to the dense city and can also be a reference for other cities to develop housing through public-private partnerships with the modern principles of integrated project financing in order to improve the welfare of low-income communities through decent housing needs.

\section{REFERENCES}

[1] S. Dikun, Indonesia Infrastructure Development, BAPPENAS, Jakarta, 2005.

[2] Public Private Partnership in Infrastructure Development, Presidential Decree Republic of Indonesia, no. 67, 2005,

[3] J. W. Creswell, A Research Design: Qualitative, Quantitative and Mixed Methods Approaches, Sage Publication, London, 2009.

[4] Center Bureau for Statistic, Jakarta in numbers. (2007). [Online]. Available: http://www.bps.go.id

[5] L. K. L. Grac, and H. W. Chan Edwin, "Factor afecting urban renewal in high density city," Journal Urban Planning and Development, Case Study in Hongkong, vol. 134-ASCE Research Library, 2008.

[6] N. S. Grigg, Infrastructure Engineering and Management, John Wiley \& Sons, New York, 1988.

[7] S. Angel, Housing Policy Matters, Forthcoming from Oxford University Press, 2000.

[8] C. Hardcastle and K. Boothroyd, "Risks overview in public-private partnership," Public-private Partnerships: Managing Risks and Opportunities, ed. A. Akintoye, M. Beck, and C. Hardcastle, New York: Wiley-Blackwell, 2003, pp. 31-58.

[9] Working in partnership to create sustainable communities. (December 2004). [Online]. Available: http://www.housing.nsw.gov.au

[10] J. Austin and McCaffrey, "A Business leadership coalitions and public-private partnerships in American cities," Journal of Urban Affairs, pp. 24, 35-54, 2002.

[11] F. Bruce, "Mainstreaming micro-finance of housing," Housing Finance International, Journal of the Union of International Housing Finance, 2000.

[12] L. Sagalyn, "Public/private development," Journal of the American Planning Association, pp. 73, 7-22, 2007.

[13] K. F. Gotham, "A City without slums, Urban Renewal, Public Housing, and Downtown Revitalization in Kansas," American Journal of Economics and Sociology, vol. 60, no. 1, January 2001.

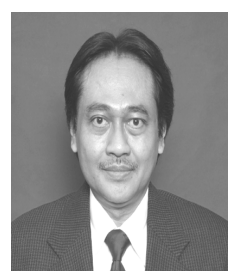

Hary Agus Rahardjo was born in Tegal, Indonesia in 1959. He got his Ph.D. degree in civil engineering from Colorado State University, USA in 2002. His research area is about Construction and Infrastructure Project Management.

Dr. Rahardjo has publication in Procedia - Social and Behavioral Sciences and in International Journal of Business and Management Studies.

Fitri Suryani was born in Pontianak Indonesia in 1967. She is Candidate Doctor in civil engineering at the University of Indonesia, Jakarta. Her research area is about Construction and Infrastructure Management.

ST. Trikariastoto was born in Sampit, Indonesia, in 1965 . He is Candidate Doctor in Architecture at the University of Indonesia, Jakarta. His research area is about housing and urban architecture. 